Manuscript version of:

Kalogeropoulou, V., Bett, B.J., Gooday, A.J., Lampadariou, N., Martinez Arbizu, P., Vanreusel, A., 2010. Temporal changes (1989-1999) in deep-sea metazoan meiofaunal assemblages on the Porcupine Abyssal Plain, NE Atlantic. Deep-Sea Research Part II, 57, 1383-1395.

\title{
Temporal changes (1989-1999) in deep-sea metazoan meiofaunal assemblages on the Porcupine Abyssal Plain, NE Atlantic.
}

\author{
V. Kalogeropoulou ${ }^{1,2^{*}}$, B. J. Bett ${ }^{3}$, A. J. Gooday ${ }^{3}$, N. Lampadariou ${ }^{1}$, \\ P. Martinez Arbizu ${ }^{2}$, A. Vanreusel ${ }^{4}$
}

${ }^{1}$ Hellenic Centre of Marine Research; P.O. Box 2214, Heraclion Crete 710 03, Greece

${ }^{2}$ DZMB-Senckenbergische Naturforschende Gesellschaft; Naturmuseum und Forschungsinstitut Senckenberg; Deutsches Zentrum fur Marine Biodiversitätsforschung, Wilhelmshaven, Germany

3 Ocean Biogeochemistry and Ecosystems Research Group; National Oceanography Centre, Southampton SO14 3ZH, UK.

${ }^{4}$ Universiteit Gent; Faculteit Wetenschappen; Vakgroep Biologie; Afdeling Mariene Biologie

* Corresponding author

vkalogeropoulou@her.hcmr.gr

vkalogeropoulou@senckenberg.de

\begin{abstract}
Trends among major metazoan meiofaunal taxa were investigated based on 56 deployments of a multicorer at 10 time points over a period of eleven years (1989-99) at a site on the Porcupine Abyssal Plain Sustained Observatory (PAP-SO: 48 $50^{\prime} \mathrm{N} 16^{\circ} 30^{\prime} \mathrm{W}, 4850 \mathrm{~m}$ depth). This area is characterised by a strong seasonality in the deposition of organic matter to the seafloor and by the massive increase in the density of holothurian species since 1996, the so-called 'Amperima event'. Total meiofaunal densities ranged from 346 to 1074 ind. $10 \mathrm{~cm}^{-2}$ and showed a significant increase with time when time was represented by cruises, years and the 'Amperima period' (1996-99) vs. the pre-Amperima period (1989-94). This pattern was driven mainly by the nematodes, which were the dominant taxon $(\sim 90 \%$ of total abundance). The third most abundant group, the polychaetes, also increased significantly in abundance over the time series, while the ostracods showed a significant decrease. Most other taxa, including the second-ranked group, the copepods (harpacticoids and nauplii), did not exhibit significant temporal changes in abundance. Ordination of taxon composition showed a shift from the pre-Amperima to the Amperima periods, a trend supported by the significant correlation between the x-ordinate and time. The majority (52-75\%) of meiofaunal animals inhabited the top $2 \mathrm{~cm}$ of the $5 \mathrm{~cm}$ sediment cores analysed. There were significant increases in the proportion of total meiofauna, nematodes and copepods (but not polychaetes) inhabiting the $0-1 \mathrm{~cm}$ layer over time (represented by cruises) and between the pre-Amperima and Amperima periods in the case of copepods and polychaetes. During the intensively sampled period (1996-97), there were indications of seasonal changes in the vertical distribution patterns of total meiofauna and nematodes within the sediment.
\end{abstract}

Keywords: meiofauna; deep sea; temporal change; abundance; vertical distribution; NE Atlantic; Porcupine Abyssal Plain 


\section{Introduction}

Quantitative studies of deep-sea meiofaunal ecology have been conducted in all major ocean basins including the Atlantic, Pacific, North Sea, Mediterranean, Red Sea, Gulf of Mexico, and Weddell Sea (e.g. Vincx et al., 1994; Soltwedel, 2000). These deep-sea investigations focused mainly on bathymetric gradients of abundance and relationships between community structure, food availability and other environmental factors. Timeseries studies are much less common. Most have been of short duration $(<5$ years) and carried out in bathyal continental margin settings (Guidi-Guilvard, 2002; Gooday, 2002; Hoste et al., 2007), although a few have extended over longer periods (Gooday et al., this volume). In the abyssal, open-ocean, studies of temporal trends in benthic communities over decadal time scales ( $>10$ years) have been conducted at only two sites, namely the Porcupine Abyssal Plain (PAP) in the NE Atlantic and Station $M$ in the NE Pacific $\left(34^{\circ} 50^{\prime} \mathrm{N}\right.$, $\left.123^{\circ} 00^{\prime} \mathrm{W}\right)$. Both these time-series studies were initiated in 1989 and have revealed long-term changes in megafaunal communities, possibly linked to climate fluctuations that influence organic matter supply (Billett et al., 2001; Ruhl \& Smith, 2004; Ruhl, 2007).

A series of European Union-funded projects conducted at the PAP site during the late 1980s and 1990s (Rice et al., 1994; Billett \& Rice, 2001) reported a strong seasonal deposition of phytodetritus (Bett et al., 2001) and a radical shift in the abundances and community structure of the invertebrate megafauna (Billett et al., 2001). This so-called 'Amperima Event' (Fig. 1) involved significant increases in the abundance of various benthic species, notably the holothurians Amperima rosea and Ellipinion molle (Bett et al., 2001; Billett et al., 2001). It is considered to be related to changes in the quantity and / or quality of organic matter reaching the seafloor (Wigham et al., 2003). This, in turn, may be influenced by climatic oscillations, although there has been no obvious trend in total organic flux to the seabed (Lampitt et al., 2001; Lampitt et al., this volume). A similar phenomenon was observed during the same period (1989-2005) in the NE Pacific, where intense fluctuations in the populations of certain species, especially holothurians, were potentially linked to climate changes (Ruhl \& Smith, 2004; Ruhl, 2007).

Apart from the observed changes in the larger benthic components, evidence is accumulating that the smaller benthic size classes at the PAP site also underwent shifts in abundance during the 1990s. Based on a study of samples from September 1996 to October 1998, Vanreusel et al. (2001) described an opheliid polychaete mass recruitment event that they interpreted as a rapid population response to a flux event. Galéron et al. (2001) demonstrated that both meiofaunal and macrofaunal taxa responded to the food pulse with increased abundance and showed vertical movements within the sediment depending on the burial of labile particulate organic matter (POM). Gooday \& Rathburn (1999) present preliminary data on foraminiferal trends over time at the PAP. Other contributions in the present volume report on temporal trends among invertebrate megafauna (Billett et al., this volume), macrofaunal polychaetes (Soto et al., this volume) and foraminifera (Gooday et al., this volume).

It is known that the seasonal deposition of phytodetritus to the deep-sea floor increases the density, activity and biomass of small faunal groups in general (Pfannkuche et al., 1999). A rapid respond of the smaller size-fractions of the benthic community, such as meiofauna, therefore might be expected. The spatial distribution of meiofauna (Rice \& Lambshead, 1994) seems to be linked to the patchy distribution of phytodetritus on the sea bed and their vertical distribution in the sediments may also be affected by the presence of phytodetritus at the sediment surface (Lambshead et al., 1995). Here we provide the first comprehensive assessment of metazoan meiofauna from the PAP site for the decade 1989-99. The main objective of this paper is to describe the trends in density and vertical distribution within the sediment of meiofauna over this 10-year period. Two questions are addressed: 1) do meiofaunal communities exhibit significant changes over long time scales, 2) are these changes similar for the different meiofaunal taxa and how do they compare to the changes observed for other faunal groups? 


\section{Materials and methods}

\subsection{Study area}

The study area is located in the centre of the Porcupine Abyssal Plain (PAP) about $270 \mathrm{~km}$ southwest of Ireland (PAP-SO, $48^{\circ} 50^{\prime} \mathrm{N}, 16^{\circ} 30^{\prime} \mathrm{W}$ ) at $4850 \mathrm{~m}$ water depth (Fig. 2). It has been sampled frequently for more than 15 years under a series of European Union-funded projects (Billett \& Rice, 2001). The PAP site is characterised by an absence of significant topography, making the benthic environment spatially uniform and remote from both the continental slope and the foothills of the mid-ocean ridge. The site is not significantly influenced by benthic storms or by down slope processes. It is characterised, however, by large seasonal variations in the flux of particulate organic matter (POM) derived from surface production (Rice et al., 1994; Lampitt et al., 2001; Lampitt et al., this volume). Fluxes are highest during the summer months, late May or early June, although peaks sometimes occur later in the year (Lampitt et al., this volume). As in other parts of the NE Atlantic, the settling material sometimes forms a patchy carpet of phytodetritus on the seabed (Thiel et al., 1989), although this was notably absent during the later years of the time series (Bett et al., 2001). During the most intensively sampled period (1996-98), seasonal changes were evident in organic compounds such as labile lipids (Kiriakoulakis et al., 2001) and phytopigments (Fabiano et al., 2001; Witbaard et al., 2001). Near-bottom current speeds are low, with a mean speed of $3.5 \mathrm{~cm} \mathrm{~s}^{-1}$ and maximum of 9 $\mathrm{cm} \mathrm{s}^{-1}$ (Vangriesheim et al., 2001). The sediment consists of biogenic carbonates, characterised as foraminiferal ooze, with a median grain size of $8.3 \mu \mathrm{m}$ (Varnavas et al., 2001) and a sedimentation rate of 3.5 $\mathrm{cm} \mathrm{ky}^{-1}$ (Rice et al., 1991). Oxygen concentration profiles show a decrease from $266 \mu \mathrm{mol} \mathrm{l}^{-1}$ at the sediment water interface to $25 \mu \mathrm{mol} 1^{-1}$ at depths ranging from about $6.2 \mathrm{~cm}$ in September 1996 to $7.5 \mathrm{~cm}$ in July 1997 and about $10 \mathrm{~cm}$ in March 1997 (Witbaard et al., 2000). The surficial sediment has a total organic carbon content of about $0.35 \%$ decreasing to $0.15 \%$ at $18 \mathrm{~cm}$ depth (Rabouille et al., 2001); the $\mathrm{C}: \mathrm{N}$ ratio varies between 4.8 and 7.8 (Santos et al., 1994).

\subsection{Shipboard procedures}

Samples were collected using a hydraulically-damped, SMBA-type multiple corer (Barnett et al., 1984), equipped with 12 core tubes of $57 \mathrm{~mm}$ internal diameter. A total of 56 undisturbed core samples, obtained from 44 separate corer deployments during 10 cruises to the PAP, were analysed for meiofaunal metazoans (Fig. 2, Table 1). Immediately after recovery, the cores were processed as follows in the ships' constant temperature laboratories $\left(5-8^{\circ} \mathrm{C}\right)$. Any phytodetritus present, together with a small volume (1-2 $\mathrm{ml}$ ) of surface sediment, was removed using a Pasteur pipette and stored separately, together with the lower few centimetres of overlying water. The core was then cut into horizontal slices by extruding it into a ring and slicing the sediment with a metal plate. During earlier cruises (1989-94, Stations 11908, 52701, 53201), the cores were cut into $1-\mathrm{cm}$-thick slices to a depth of at least $10 \mathrm{~cm}$. From 1996 onwards, the cores were cut into $0.5-\mathrm{cm}$ slices to a depth of $2 \mathrm{~cm}$ and thereafter into $1-\mathrm{cm}$ slices to at least $10 \mathrm{~cm}$ depth. All samples were fixed in $4 \%$ formalin buffered with sodium borate (borax), made up with filtered $(32 \mu \mathrm{m})$ seawater.

\subsection{Laboratory procedures}

The core samples were analysed to a depth of $5 \mathrm{~cm}$. Meiofauna are conventionally defined to include animals that pass through a $1000-\mu \mathrm{m}$ mesh sieve and are retained on a 63- $\mu \mathrm{m}$ mesh sieve (Giere, 1993).

However, because deep-sea organisms are generally smaller than their shallow-water counterparts (Kaariainen \& Bett, 2006), a 32- $\mu \mathrm{m}$ mesh sieve was used as the lower limit in this study. Meiofauna were extracted by density gradient centrifugation with Ludox as a flotation medium (de Jonge \& Bouwman, 1977). The technique typically extracts $95-99 \%$ of organisms over all sediment grain sizes (Burgess, 2001). The treated samples were stained with Rose Bengal ( $0.5 \mathrm{~g} \mathrm{l}^{-}$ ${ }^{1}$ ) and all metazoan meiofaunal taxa were counted and sorted under a stereoscopic microscope. Although the samples were sorted by different people in two laboratories (DZMB and Universiteit Gent), there were no statistically significant differences between counts of samples from the same cruise (paired t-test; $p>0.05$ ). Both temporary and permanent meiofaunal taxa were analysed.

\subsection{Statistical methods}

Univariate statistical procedures were carried out using the $\operatorname{Minitab}^{\circledR}$ (v. 15.1.1.0., Minitab Inc.) software package; all methods employed are as described by Zar (1999). Prior to the analyses, data from multiple samples from single deployments (e.g. a, b and c samples indicated in Table 1) were averaged to a single representative sample, i.e. only true replicates (from independent deployments) were included in the analyses. Variations in meiofaunal density were assessed by analysis of variance (ANOVA), the data having first been subject to a $\log (\mathrm{x}+1)$ transformation in an attempt to 'improve' normality and homoscedasticty (e.g. Bartlett's test of log-transformed total meiofauna data assessed by year gives a non-significant result, $\mathrm{p}>0.05)$. ANOVA was also employed to examine variations in the vertical distribution of meiofaunal taxa using the percentage of specimens recovered in the $0-1$ $\mathrm{cm}$ layer, relative to the total recovered in the $0-5 \mathrm{~cm}$ sample, as an indicator of vertical distribution. These percentage data were subject to an arcsine transformation prior to analyses in an attempt to 'improve' normality. For presentation, both the density and vertical distribution results are shown with $95 \%$ confidence intervals based on pooled variances; note that in the case of density, back transformation yields geometric mean (not arithmetic mean) values. Some correlation analyses were also carried out (as described in the results section below); in all cases these were implemented using the Spearman's rank (nonparametric) technique.

Potential variation in meiofaunal taxon composition was assessed by multivariate analyses (cluster analysis and non-metric multidimensional scaling ordination) using the PRIMER (v. 5.2.0, PRIMER-E Ltd) software package. The Bray-Curtis similarity index was employed in all analyses (Clarke \& Green, 1988). The significance of taxon composition variation between periods (pre-Amperima to Amperima) was assessed by analysis of similarities (ANOSIM); a range of data transformations (none, $\sqrt{ }, \sqrt{ } \sqrt{ }$ and $\log [\mathrm{x}+1])$ was tested. 


\section{Results}

\subsection{Meiofaunal assemblage composition}

Meiofaunal organisms, belonging to 14 major taxa, were extracted from the core samples collected between 1989 and 1999. Nematodes were clearly the dominant group, representing $68-96 \%$ of the assemblage; harpacticoid copepods, including all developmental stages, were the second most abundant taxon, contributing $3-14 \%$ to the total; polychaetes were the third most abundant representing $0.2-4.4 \%$ of the meiofauna. The latter were dominated $(>97 \%)$ by larval specimens of an opheliid, as reported by Vanreusel et al. (2001). Other taxa, namely oligochaetes, gastrotrichs, ostracods, tardigrades, loriciferans, kinorhynchs, molluscs, nemertines and tantulocarids, were regularly found but in very low abundances and generally contributed no more than $1 \%$ to the assemblage. Rotifers and halacarids were also encountered during sample processing; these are believed to be contaminants either from clothe fibers, or plastic vials, i.e. halacarids, or tap water, i.e. rotifers (personal communication Pedro Martinez Arbizu) and have been excluded from all results presented here.

\subsection{Temporal changes in densities}

Mean abundances of metazoan meiofauna and major taxa are summarised in Table 2 and trends in mean densities of selected taxa over time are shown in Figure 3. Mean densities of total meiofauna ranged from the lowest (346 ind. $10 \mathrm{~cm}^{-2}$ ) in April 1994 to the highest (1074 ind. $10 \mathrm{~cm}^{-2}$ ) in April 1999 and increased from an overall mean of 475 ind. $10 \mathrm{~cm}^{-2}$ during the 1989-94 period to 824 ind. $10 \mathrm{~cm}^{-2}$ in the $1996-99$ period. The dominant taxon, the nematodes, also showed a threefold density range from the lowest (301 ind. $10 \mathrm{~cm}^{-2}$ ) in April 1994 to the highest $\left(935\right.$ ind. $10 \mathrm{~cm}^{-2}$ ) in April 1999. Mean nematode densities increased over the time series from 418 ind. $10 \mathrm{~cm}^{-2}$ (1989-94) to 740 ind. 10 $\mathrm{cm}^{-2}$ (1996-99). Polychaete densities were even more variable, ranging from 2 ind. $10 \mathrm{~cm}^{-2}$ (August 1989) to 19 ind. $10 \mathrm{~cm}^{-2}$ (September 1996) with means of 3 ind. $10 \mathrm{~cm}^{-2}$ (1989-94) and 11 ind. $10 \mathrm{~cm}^{-2}$ (1996-99) during the earlier and later parts of the time series.

Harpacticoid copepods (including their nauplii) fluctuated in abundance with the highest peaks in May 1991 (55 ind. $10 \mathrm{~cm}^{-2}$ ) and April 1999 (58 ind. $10 \mathrm{~cm}^{-2}$ ). However, mean densities during the 1989-94 and 199699 periods were similar (42 and 45 ind. $10 \mathrm{~cm}^{-2}$; Table 2).

ANOVA revealed that the densities of total metazoan meiofauna, as well as those of nematodes and polychaetes, increased significantly $(p<0.001)$ over time, when time was represented by cruises, years and periods (i.e. 1989-94 vs. 1996-99) (Table 2; Fig. 3). Several other taxa (oligochaetes, gastrotrichs, ostracods, kinorhynchs) showed significant $(\mathrm{p}<0.05)$ variations when time was represented in one or more of these ways (Table 2). However, the densities of copepods and some of the less common taxa did not change significantly over time. When density data were arranged by month, irrespective of year, significant variations were found only for polychaetes, oligochaetes and ostracods (Table 2).
Hierarchical cluster analysis and multidimensional scaling analysis were carried out on meiofaunal taxon composition without performing any data transformation. The two-dimensional plot revealed a fairly good separation, although with some overlap, between samples from the pre-Amperima (1989-94) and Amperima (1996-99) periods (Fig. 4a). There was also a significant correlation $\left(\mathrm{r}_{\mathrm{s}} 0.617, \mathrm{p}<0.001\right)$ between nMDSx-axis values and time (Fig. 4b), driven mainly by the changes in nematode and polychaete density. ANOSIM results strongly support the pre-Amperima to Amperima period variation ( $\mathrm{p}$ values range from 0.001 to 0.006 , depending on transformation), again largely reflecting the increasing abundances of nematodes and polychaetes.

\subsection{Vertical distribution}

Vertical distribution profiles of the major meiofaunal taxa are shown in Figure 5. Densities decreased with sediment depth with the single exception of nematodes in the August 1989 samples, where similar densities were present in both the 0-1 and 1-2 cm layers.

Assessed across all samples, the median proportion of specimens present in the $0-1 \mathrm{~cm}$ layer was $44.9 \%$ (36.8$51.6 \%$ interquartile range) for the total meiofauna, with similar median values for the nematodes (median: $43.0 \% ; 35.0-49.8 \%$ interquartile range). Copepods were more superficially distributed (median: $67.9 \%$; 62.0 $75.1 \%$ interquartile range), with polychaetes largely restricted to the surface layer (median: $81.1 \%$; 73.3$95.1 \%$ interquartile range).

Temporal trends in the vertical distribution of meiofaunal taxa, assessed on the basis of the relative abundance of specimens in the $0-1 \mathrm{~cm}$ layer, were examined by ANOVA (Fig. 6, Table 3). Significant variations were found between months (irrespective of year) for nematodes $(\mathrm{p}<0.001)$, copepods $(\mathrm{p}=0.010)$ and total meiofauna $(\mathrm{p}<0.001)$. Significant (see Table 3 ) temporal variations were also detected between cruises (nematodes, copepods and total meiofauna), years (copepods) and periods (copepods and polychaetes) (Table 3). Both copepods and polychaetes were concentrated closer to the surface sediment in the 199699 (Amperima) period; the median relative abundance of copepods in the $0-1 \mathrm{~cm}$ layer increasing from $55.6 \%$ (51.1-63.9\% interquartile range) to $69.6 \%$ (63.7-78.1\% interquartile range) and that of polychaetes increasing from $64.6 \%$ (43.8-97.9\% interquartile range) to $88.9 \%$ (77.4-94.7\% interquartile range) between periods, respectively. 


\section{Discussion}

4.1. Comparison of PAP meiofauna standing stocks with other deep-sea areas

The number of higher taxa (14 excluding rotifers and halacarids) in our PAP time-series samples, and the dominance of nematodes ( $>90 \%$ of the total meiofauna) followed by harpacticoid copepods and polychaetes, is consistent with previous studies of deep-sea meiofauna (Thiel, 1983; Shirayama, 1984a; Tietjen et al., 1989; Alongi, 1992; Vincx et al., 1994; Vanhove et al., 1995; Vanreusel et al., 2000). Total meiofaunal abundances at the PAP ranged from 200 to 1417 ind $10 \mathrm{~cm}^{-2}$, with mean values per time point ranging from 347 to 1074 ind. $10 \mathrm{~cm}^{-2}$. Previous studies have reported abundances of the same order of magnitude in deep eastern Atlantic basins (Pfannkuche, 1985; Soltwedel, 1997) and lower values, by up to a factor of two, in western basins (Tietjen et al., 1989; Thistle et al., 1991; Tietjen, 1992; Soltwedel, 2000). According to Soltwedel (2000), meiofaunal abundances in polar regions are approximately twice as high as those in temperate areas such as the PAP. On the other hand, densities in subtropical Atlantic regions, as well as in the Western and Eastern Mediterranean and the northwest Indian Ocean, are 2-3 times lower (Dinet \& Vivier, 1977; Tahey et al., 1994; Danovaro \& Fabiano, 1995; Tselepides \& Lampadariou, 2004) than those at the PAP. In abyssal Pacific basins, meiofaunal densities are similar to those in our samples (Shirayama, 1984a ; Alongi, 1992).

These geographical variations in meiofaunal densities at similar abyssal depths can be explained by differences in productivity. The PAP is a relatively eutrophic area with strong seasonal fluxes (Lampitt \& Antia, 1997; Lampitt et al., 2001), whereas much lower POM fluxes have been reported at several sites in the western Atlantic (Lampitt \& Antia, 1997). The Mediterranean, particularly the Eastern basin, is characterised by very low standing stocks, reflecting the very low primary productivity of the area (Danovaro et al., 1995a). Rex et al. (2006) compiled a global dataset of meiofaunal abundance, their regression equation predicts an abundance of 206 ind. $10 \mathrm{~cm}^{-2}$ for a water depth of $4850 \mathrm{~m}$. This value is some 2-4 times lower than the period mean values at the PAP (1989-94, 475 ind. $10 \mathrm{~cm}^{-2}$; $1996-99,824$ ind. $10 \mathrm{~cm}^{-2}$ ) supporting the relatively eutrophic status of the site. Moreover, Mokievskii et al. (2007) presented a stable correlation between the abundance of meiofauna in the deep sea and the productivity of the surface water. The results of the present study clearly suggest that, as in other oceanic regions, meiofaunal organisms at the PAP are sensitive to food supply and that they show a similar response to carbon limitation in terms of standing stock (Pfannkuche, 1993; Vincx et al., 1994).

\subsection{Meiofaunal response to phytodetritus fluxes}

When densities of the total meiofauna and of individual taxa from this study were arranged by month, irrespective of year, the only numerically important group to exhibit significant variations, were the polychaetes (Table 2). In our samples, this taxon was dominated by juvenile opheliids. Vanreusel et al. (2001) studied the abundance and size spectra of these small worms during the period September 1996 to October 1998. They found evidence for a recruitment event in 1996, when populations were dominated by small individuals, followed by growth of the cohort in terms of body size over the next two years.

It is difficult to interpret seasonal data compiled from different years. However, the lack of a significant seasonal pattern in other taxa, notably the nematodes and harpacticoids (Table 2), contrasts with the strong seasonal signal in the organic matter flux detected by sediment traps (Lampitt et al., 2001; Lampitt et al., this volume). Similarly, there were no seasonal changes in meiofaunal densities at a nearby site (BIOTRANS, $47^{\circ} \mathrm{N}, 20^{\circ} \mathrm{W}, 4450 \mathrm{~m}$ water depth) in the abyssal NE Atlantic (Pfannkuche, 1992; 1993), or in the bathyal NE Atlantic (Gooday et al., 1996) and NW Pacific (Shimanaga \& Shirayama, 2000). However, at the BIOTRANS site, Soltwedel et al. (1996) observed significant increase in nematode size spectra, indicating intense reproductive activity and therefore seasonal recruitment stimulated by the increased input of organic matter. Moreover, there are indications in our data of a response by some taxa during the intensively sampled period between 1996 and 1997 (Billett \& Rice, 2001). As noted by Galeron et al. (2001), total meiofauna, nematodes and harpacticoids decrease in abundance between September 1996 (when phytodetritus was present; Bett et al., 2001) and March 1997. Our new data show that the same groups increased in abundance between March 1997 and July 1997, when a 'faint green veneer' was observed on the seafloor and chlorophyll-a values in surficial sediments were higher compared to March 1997 (Witbaard et al., 2000). More detailed sampling during other years may have revealed similar seasonal variations. It is also possible that the metazoan meiofauna exhibit time-lagged responses to food pulses, similar to those reported in the North Sea (Faubel et al., 1983), Kiel Bight (Graf et al., 1982, 1984) and the deep Eastern Mediterranean (Danovaro et al., 2000).

\subsection{Multi-year trends}

Over the decadal time scale, total meiofaunal abundances increased significantly in 1996 and persisted at a similar or even higher level until 1999, showing a significant correlation with time. The densities of nematodes and polychaetes exhibited a similar trend. These changes paralleled those in other faunal groups. Among the macrobenthos, Galéron et al. (2001) observed an increase in population densities that lagged behind the timing of POM input. Soto et al. (this volume) report increases in the abundance of macrofaunal polychaetes, particularly surface depositfeeding taxa. Gooday et al. (this volume) report that the densities of live foraminifera, and particularly trochamminaceans, were significantly higher in 19962002 than in 1989-94. Most remarkably, there was a spectacular rise in the abundance of megafauna, particularly the holothurians Amperima rosea and Ellipinion molle, over the same time period (Billett et al., 2001). Similar long-term shifts in the abundance of megafaunal animals are documented at Station $\mathrm{M}$ in the NE Pacific (Ruhl \& Smith, 2004; Ruhl 2007). Short- 
term temporal changes without any seasonality, recorded for the meiofaunal assemblages in adjacent areas in the NE Atlantic (Pfannkuche, 1993) as well as the NW Pacific (Shimanaga \& Shirayama, 2000), are consistent with the results of the current study. Studies with ${ }^{13} \mathrm{C}$-labelled phytodetritus at PAP have shown that macrobenthic (and presumably megabenthic) organisms can effectively out compete meiobenthos and bacteria in terms of the immediate consumption of newly arrived phytodetritus (Witte et al., 2003).

The rise in meiofaunal densities is coincident with increased activity by megafaunal animals (Bett et al., 2001). Large consumers play an important role in the removal and repackaging of POM (Jumars \& Self, 1986; Boudreau, 1994), strongly interacting with the meiofauna, as suggested by the in situ experiment conducted by Thistle et al. (2008). Moreover, Gallucci et al. (2008) are suggesting that larger benthic organisms influence significantly nematode assemblages, although megafauna may not fully account for the high nematode species coexistence in deep-sea sediments. At the PAP, the massive increase in the abundance of megafaunal detritus feeders referred to above meant that fresh POM was consumed rapidly, reworked and repackaged into smaller aggregates, which may then have been available to the infaunal meiobenthos. This repackaging may also have altered bacterial populations, which may also be a key resource for the meiobenthos. The increased densities of large animals may also have favoured 'disturbance opportunists', as suggested by Gooday et al. (this volume) in the case of foraminifera at the PAP.

\subsection{Contrasting responses by metazoan meiofauna and foraminifera.}

In a general sense, the overall increase in abundance of metazoan meiofauna over time resembles the temporal patterns shown by the foraminifera (Gooday et al., this volume). Nevertheless, meiofaunal animals are often less responsive than foraminifera to episodic pulses of phytodetritus (Pfannkuche, 1993; Gooday et al., 1996; Gooday 2002). For example, in the bathyal Porcupine Seabight, there was no obvious increase in the abundance of metazoan meiofauna following a phytodetrital input, whereas the foraminifera exhibited a clear response. The foraminiferal response is most evident in the case of the small, opportunistic 'phytodetritus species' that undergo short-term fluctuations in population densities related to inputs of phytodetritus (e.g., Gooday, 1988; Gooday et al., 1992; Ohga \& Kitazato, 1997; Kurbjeweit et al., 2000; Kitazato et al., 2000; Gooday \& Hughes 2002). Over the course of the PAP time series, several groups, particularly the trochamminaceans, showed substantial increases in abundance. The ability of foraminifera to respond in this way seems to reflect their opportunistic life-histories (Gooday, 1993), highly efficient foodgathering mechanisms and an ability to rapidly activate their metabolic processes after periods of dormancy (Linke 1992; Gooday et al., 1992). As a group, however, the metazoan meiofauna seem to have generally slower turnover rates as well as energy requirements for egg production. Moreover, the predominantly bacterial diets of many deep-sea nematodes probably makes them less directly dependent on inputs of fresh phytoplankton-derived material than opportunistic, shallow-infaunal foraminifera.

Similar lifestyles and, consequently, responses to varying phytodetrital flux and megafaunal reprocessing may be evident among the polychaetes. The harpacticoids, however, exhibited no significant temporal change in their abundance (neither by month, cruise, year nor between pre-Amperima and Amperima periods). These copepods may be predominantly surface feeders, and certainly their shallow-water counterparts can rapidly assimilate sedimented planktonic diatoms (Palmer, 1984; Decho, 1986; Rudnick, 1989) and may be closely associated with phytodetritus (Fleeger \& Shirley, 1990). It is conceivable that their lack of abundance response is as a result of intense competition with the markedly enhanced populations of surface deposit feeding megabenthos (particularly the ophiuroid Ophiocten hastatum and the holothurian Amperima rosea; Bett et al. 2001). Although, it is difficult to establish direct competition for food resources between copepods and the megabenthos, stable isotope studies at the PAP SO (Iken et al., 2001) and at two bathyal sites in Sagami Bay (Nomaki et al., 2008) do suggest that the two groups do not have distinct $\delta^{15} \mathrm{~N}$ signatures. The phytodetritus associated foraminiferan Epistominella exigua was reduced in abundance at the onset of the "Amperima Event", again potentially as a result of competition from the megabenthos (Gooday et al. this volume).

\subsection{Temporal changes in vertical distribution} Availability of organic matter and oxygen are considered to be the main factors limiting the penetration of meiofauna into the sediment (Thiel, 1983; Shirayama, 1984b; Danovaro et al., 1995b; Vanreusel et al., 1995). According to oxygen profile data (Witbaard et al., 2000), oxygen was never severely depleted in the upper $5 \mathrm{~cm}$ of sediment during our time series study. Therefore, food availability and quality were probably the main factors determining vertical distribution patterns. During most years, the sediment surface was enriched by the supply of organic matter from the water column (Witbaard et al., 2000; Lampitt et al., 2001). Our data show that all meiofaunal taxa were aggregated to a greater or lesser extent in the upper sediment layer (Fig. 5). This was consistent with the higher values of oxygen and respiration profiles found in the reactive top layer (Witbaard et al., 2000).

It is possible, however, that oxygen played some role in the decrease from September 1996 to March and July 1997 in the proportion of total meiofauna inhabiting the upper 1-cm layer (Figs. 5, 6). During September 1996, the vertical oxygen profile within the sediment was steeper compared to July 1997 and March 1997. At the same time, the relatively fresh phytodetritus present on core surfaces during September 1996 had disappeared by March 1997, the surficial layer became impoverished in both labile lipids and phytopigments, and higher quantities of phytopigments were detected in the 1-2 cm layer (Witbaard et al., 2001). Nematodes, in particular, showed a downward 
movement into the sediment, increasing in abundance in the 1-3 cm layer where they encountered more degraded organic material. In addition to the possible influence of oxygen, they may have been forced to move deeper by the availability of food in the subsurface layers and to avoid physical disturbances, such as the intense reworking of the sediment, competition or predation pressure from larger organisms coexisting in their habitat, as suggested by Thiel (1983) and Lambshead et al. (1995). It is interesting to note that the foraminiferan species Quinqueloculina sp. also migrated deeper into the sediment between September 1996 and July 1997 (Gooday et al., this volume). Our observations over this well-sampled portion of the time series support the suggestion that small infaunal species can respond on seasonal time scales to the chemical properties of the sediment by changing their vertical distributions (Danovaro et al., 1995b; Lambshead et al., 1995; Soetaert et al., 1997). There were also indications of seasonality when vertical distribution data for nematodes, copepods and total meiofauna were analysed by month, irrespective of year (Fig. 6), although it is difficult to interpret this pattern based on composite data.

Polychaetes did not penetrate deeply into the sediment at any time over the course of the study. Similarly, harpacticoids were predominantly associated with the surface sediment layer; perhaps not surprisingly given their surface feeding behaviour and possible association with phytodetritus (see section 4.4. above). Compared to adult harpacticoids and copepodites, copepod nauplii were more abundant and inhabited deeper sediment layers during May '91, April '94, July '97 and April '99, possibly suggesting enhanced reproductive activity. In marked contrast, nematodes were much more extensively distributed through the sediment column, again presumably linked with their bacterial / sub-surface deposit feeding and potentially their greater tolerance of dysoxic conditions (e.g. Heip et al. 1985).

\section{Concluding remarks}

We analysed temporal patterns among metazoan meiofauna at the higher taxon level. However, sspecies within each taxonomic group are characterized by different biological and physiological characteristics, feeding preferences, life cycles and reproduction rates. They probably react individually to changes in parameters such as the quantity and quality of available food. Therefore, some meiofaunal responses to seasonal or interannual environmental changes may be masked at the level of higher taxa (Gooday et al., 1996). Thiel et al. (1989) noted elevated abundances of nematodes on aggregates of freshly deposited phytodetritus sampled from $4500 \mathrm{~m}$ in the NE Atlantic, suggesting that metazoan meiofauna may colonise and utilize freshly sedimented material. There is a clear need for detailed microscopic observations in order to recognize species, at least for the dominant groups, the nematodes and harpacticoid copepods. These should be coupled with morphological studies of mouthparts and other structures from which aspects of their trophic ecology could be inferred. In this way, it may be possible to detect any short-term or long-term changes that have occurred in the structure and composition of meiofaunal assemblages over the PAP time series.

\section{Acknowledgements}

The authors would like to thank the officers and crews of RRS Discovery and RRS Challenger over many years. The work was funded, in part, by EC contract MAS-3 950018. Vasiliki Kalogeropoulou received financial support from the responsive mode project DEEPSETS (Deep-sea \& Extreme Environments, Patterns of Species and Ecosystem Time Series) of the EU FP6 Network of Excellence MarBEF (contract no. GOCE-CT-2003-505446). This work also contributes to the Census of Marine Life field project "CeDAMar" and the UK Natural Environment Research Council's Strategic Research Project "Oceans 2025". 
References

Alongi, D.M., 1992. Bathymetric patterns of deep-sea benthic communities from bathyal to abyssal depths in the western South Pacific (Solomon and Coral Seas). Deep Sea Research Part I, 39, 549-565.

Barnett, P.R.O., Watson, J., Connelly, D., 1984. The multiple corer for taking virtually undisturbed samples from shelf, bathyal and abyssal sediments. Oceanologica Acta, 7, 399-408.

Bett, B.J., Malzone, M.G., Narayanaswamy, B.E., Wigham, B.D., 2001. Temporal variability in phytodetritus and megabenthic activity at the seabed in the deep Northeast Atlantic. Progress in Oceanography, 50, 349-368.

Billett, D.S.M., Rice, A.L., 2001. The BENGAL programme: introduction and overview. Progress in Oceanography, 50, 13-25.

Billett, D.S.M., Bett, B.J., Rice, A.L., Thurston, M.H., Galeron, J., Sibuet, M., Wolff, G.A., 2001. Long-term change in the megabenthos of the Porcupine Abyssal Plain (NE Atlantic). Progress in Oceanography, 50, 325-348.

Billett, D.S.M., Bett B.J., Reid, W.D.K., Boorman, B. Priede, M., in press. Long-term change in the abyssal NE Atlantic: The 'Amperima Event' revisited. Deep Sea Research Part II, this volume

Boudreau, B.P., 1994. Is burial velocity a master parameter for bioturbation. Geochimica et Cosmochimica Acta, 58, 1243-1249.

Burgess, R., 2001. An improved protocol for separating meiofauna from sediment using colloidal silica sols. Marine Ecology Progress Series, 214, 161-165.

Clarke, K.R., Green, R.H., 1988. Statistical design and analysis for a 'biological effects' study. Marine Ecology Progress Series, 46, 213-226.

Danovaro, R., Fabiano, M., 1995. Meiofaunal abundance and distribution in bathyal sediments of the Mediterranean Sea: an overview. Biologia Marina Mediterranea, 2, 217-225.

Danovaro, R., Croce, N.D., Eleftheriou, A., Fabiano, M. Papadopoulou, K.N., Smith, C., Tselepides, A., 1995a. Meiofauna of the deep Eastern Mediterranean Sea: distribution and abundance in relation to bacterial biomass, organic matter composition and other environmental factors. Progress in Oceanography, 36, 329-341.

Danovaro, R., Fabiano, M., Albertelli, G., Della Croce, N., 1995b. Vertical distribution of meiofauna in bathyal sediments of the eastern Mediterranean Sea: relationship with labile organic matter and bacterial biomasses. Marine Ecology, 16, 103-116.

Danovaro, R., Marrale, D., Dell'Anno, A., Della Croce, N., Tselepides, A., Fabiano, M., 2000. Bacterial response to seasonal changes in labile organic matter composition on the continental shelf and bathyal sediments of the Cretan Sea. Progress in Oceanography, 46, 345-366.

Danovaro, R., Tselepides, A., Otegui, A., Della Croce, N., 2000. Dynamics of meiofaunal assemblages on the continental shelf and deep-sea sediments of the Cretan Sea (NE Mediterranean): relationships with seasonal changes in food supply. Progress in Oceanography, 46, 367-400.

Decho, A.W., 1986. Water-cover influence on diatom ingestion rates by meiobenthic copepods. Marine Ecology Progress Series, 33, 139-146.

De Jonge, V.N., Bouwman, L.A., 1977. A simple density separation technique for quantitative isolation of meiobenthos using the colloidal silica Ludox-TM. Marine Biology, 42, 143-148.

Dinet, A., Vivier, M.H., 1977. Le meiobenthos abyssal du Golfe de Gascogne. Cahiers de Biologie Marine, 18, 85-97.

Fabiano, M., Pusceddu, A., Dell'Anno, A., Armeni, M., Vanucci, S. Lampitt, R.S., Wolff, G.A., Danovaro, R., 2001. Fluxes of phytopigments and labile organic matter to the deep ocean in the NE Atlantic Ocean. Progress in Oceanography, 50, 89-104.

Faubel, A., Hartwig, E., Thiel, H., 1983. On the ecology of the benthos of sublittoral sediments, Fladen Ground, North Sea. I. Meiofauna standing stock and estimation of production. Meteor Forschungs Ergebnisse, 36, 35-48.

Fleeger, J.W., Shirley, T.C., 1990. Meiofaunal responses to sedimentation from an Alaskan spring bloom. II. Harpacticoid population dynamics. Marine Ecology Progress Series, 59, 239 247.

Galéron, J., Sibuet, M., Vanreusel, A., Mackenzie, K., Gooday, A.J., Dinet, A., Wolff, G.A., 2001. Temporal patterns among meiofauna and macrofauna taxa related to changes in sediment geochemistry at an abyssal NE Atlantic site. Progress in Oceanography, 50, 303-324.
Galluci, F., Fonseca, G., Soltwedel, T., 2008. Effects of megafauna exclusion on nematode assemblages at a deep-sea site. Deep Sea Research Part I: Oceanographic Research Papers, 55, 332-349.

Giere, O., 1993. Meiobenthology; the microscopic fauna in aquatic sediments. Springer-Verlag, Berlin.

Gooday, A.J., 1988. A response by benthic foraminifera to phytodetritus deposition in the deep sea. Nature, 332, 70-73.

Gooday, A.J., 1993. Deep-sea benthic foraminiferal species which exploit phytodetritus: characteristic features and controls on distribution. Marine Micropaleontology 22, 187-205.

Gooday, A.J., 2002. Biological responses to seasonally varying fluxes of organic matter to the ocean floor: a review. Journal of Oceanography, 58, 305-332.

Gooday, A.J., Hughes, J.A., 2002. Foraminifera associated with phytodetritus deposits at a bathyal site in the northern Rockall Trough (NE Atlantic); seasonal contrasts and a comparison of stained and dead assemblages. Marine Micropaleontology, 46, 83110.

Gooday, A.J., Rathburn, A.E., 1999. Temporal variability in living deep-sea benthic foraminifera: a review. Earth-Science Reviews, $46,187-212$

Gooday, A.J., Levin, L.A., Linke, P., Heeger, H., 1992. The role of benthic Foraminifera in deep-sea food webs and carbon cycling. In: Rowe, G.T., Pariente, V. (Eds), Deep-Sea Food Chains and the Global Carbon Cycle. Kluwer Academic Publishers, The Netherlands, pp. 63-91.

Gooday, A.J., Pfannkuche, O., Lambshead, P.J.D., 1996. An apparent lack of response by metazoan meiofauna to phytodetritus deposition in the bathyal north-eastern Atlantic. Journal of the Marine Biological Association of the United Kingdom, 76, 297310.

Gooday, A.J., Malzone, M.G., Bett, B.J., Lamont, P.A., in press. Decadal-scale changes in shallow-infaunal foraminiferal assemblages at the Porcupine Abyssal Plain, NE Atlantic. Deep Sea Research Part II, this volume.

Graf, G., Bengtson, W., Diesner, U., Schulz, R., Theede, H., 1982. Benthic response to sedimentation of a spring phytoplankton bloom: processes and budget. Marine Biology, 67, 201-208.

Graf, G., Bergtsson, W., Faubel, A., Meyer-Reil, L.A., Schulz, R. Theede, H., Thiel, H., 1984. The importance of the spring bloom for the benthic system of Kiel Bight. Rapports et Proces-Verbaux des Réunions du Conseil International pour l'Exploration de la Mer, 183, 136-143.

Guidi-Guilvard, L.D., 2002. DYFAMED-BENTHOS, a long timeseries benthic survey at 2347-m depth in the northwestern Mediterranean: general introduction. Deep Sea Research Part II, 49, 2183-2193.

Heip, C., Vincx, M., Vranken, G., 1985. The ecology of marine nematodes. Oceanography and Marine Biology Annual Review, 23, 399-489.

Hoste, E., Vanhove, S., Schewe, I., Soltwedel, T., Vanreusel, A., 2007. Spatial and temporal variations in deep-sea meiofauna assemblages in the Marginal Ice Zone of the Arctic Ocean. Deep Sea Research I, 54, 109-129.

Iken, K., Brey, T., Wand, U., Voigt, J., Junghans, P., 2001. Food web structure of the benthic community at the Porcupine Abyssal Plain (NE Atlantic): a stable isotope analysis. Progress in Oceanography, 50, 383-405.

Jones, P.D., Jonsson, T., Wheeler, D., 1997. Extension to the North Atlantic Oscillation using early instrumental pressure observations from Gibraltar and South-West Iceland. International Journal of Climatology, 17, 1433-1450.

Jumars, P.A., Self, R.F.L., 1986. Gut-marker and gut-fullness methods for estimating field and laboratory effects of sediment transport on ingestion rates of deposit-feeders. Journal of Experimental Marine Biology and Ecology, 98, 293-310.

Kaariainen, J.I., Bett, B.J., 2006. Evidence for benthic body size miniaturization in the deep sea. Journal of the Marine Biological Association of the UK, 86, 1339-1345.

Kiriakoulakis, K., Stutt, E., Rowland, S.J., Vangriesheim, A., Lampitt, R.S., Wolff, G.A., 2001. Controls on the organic chemical composition of settling particles in the Northeast Atlantic Ocean. Progress in Oceanography, 50, 65-87.

Kitazato, H., Shirayama, Y., Nakatsuka, T., Fujiwara, S., Shimanaga, M., Kato, Y., Okada, Y., Kanda, J., Yamaoka, A., Masuzawa, T., Suzuki, K., 2000. Seasonal phytodetritus deposition and responses of bathyal benthic foraminiferal populations in Sagami Bay, Japan: preliminary results from 'Project Sagami 1996-1999'. Marine Micropaleontology 40, 135-149. 
Kurbjeweit, F., Schmiedl, G., Schiebel, R., Hemleben, Ch. Pfannkuche, O., Wallmann, K., Schäfer, P., 2000. Distribution, biomass and diversity of benthic foraminifera in relation to sediment geochemistry in the Arabian Sea. Deep Sea Research Part II 47, 2913-2955.

Lambshead, P.J.D., Ferrero, T.J., Wolff, G.A., 1995. Comparison of the vertical distribution of nematodes from two contrasting abyssal sites in the northeast Atlantic subject to different seasonal inputs of phytodetritus. Internationale Revue der gesamte Hydrobiologie, 80, 327-331.

Lampitt, R.S., Antia, A., 1997. Particle flux in deep seas: regional characteristics and temporal variability. Deep Sea Research Part I, 44, 1377-1403.

Lampitt, R.S., Bett, B.J., Kiriakoulakis, K., Popova, E.E., Ragueneau, O., Vangriesheim, A., Wolff, G.A., 2001. Material supply to the abyssal seafloor in the Northeast Atlantic. Progress in Oceanography, 50, 27-63

Lampitt, R.S., de Cuevas, B., Hartman, S., Larkin, K., Salter, I., in press. Inter-annual variability in downward particle flux at the Porcupine Abyssal Plain Sustained Observatory. Deep Sea Research Part II, this volume.

Linke, P., 1992. Metabolic adaptations of deep-sea benthic foraminifera to seasonally varying food input. Marine Ecology Progress Series, 81, 51-63.

Mokievskii, V.O., Udalov, A.A., Azovskii, A.I., 2007. Quantitative distribution of meiobenthos in deep-water zones of the World Ocean. Oceanology, 47 (6), 857-874.

Nomaki, H., Ogawa, N.O., Ohkouchi, N., Suga, H., Toyofuku, T., Shimanaga, M., Nakatsuka, T., Kitazato, H., 2008. Benthic foraminifera as trophic links between phytodetritus and benthic metazoans: carbon and nitrogen isotopic evidence. Marine Ecology Progress Series, 357, 153-164.

Ohga, T., Kitazato, H., 1997. Seasonal changes in bathyal foraminiferal populations in response to the flux of organic matter (Sagami Bay, Japan). Terra Nova, 9, 33-37.

Palmer, M.A., 1984. Invertebrate drift: behavioural experiments with intertidal meiobenthos. Marine Behaviour and Physiology, 10, $235-225$

Pfannkuche, O., 1985. The deep-sea meiofauna of the Porcupine Seabight and abyssal plain (NE Atlantic): population structure, distribution, standing stocks. Oceanologica Acta, 8, 343-353.

Pfannkuche, O., 1992. Organic carbon flux through the benthic community in the temperate abyssal northeast Atlantic. In: Rowe, G.T., Pariente, V. (Eds), Deep-Sea Food Chains and the Global Carbon Cycle. Kluwer Academic Publishers, The Netherlands, pp. 183-198.

Pfannkuche, O., 1993. Benthic response to the sedimentation of particulate organic matter at the BIOTRANS station, $47^{\circ} \mathrm{N}, 20^{\circ} \mathrm{W}$ Deep Sea Research Part II, 40, 135-149.

Pfannkuche, O., Boetius, A., Lochte, K., Lundgreen, U., Thiel, H., 1999. Responses of deep-sea benthos to sedimentation patterns in the North-East Atlantic in 1992. Deep Sea Research Part I, 46, 573-596.

Rabouille, C., Witbaard, R., Duineveld, G.C.A., 2001. Annual and interannual variability of sedimentary recycling studied with a non-steady-state model: application to the North Atlantic Ocean (BENGAL site). Progress in Oceanography, 50, 147-170.

Rex, M.A., Etter, R.J., Morris, J.S., Crouse, J., McClain, C.R., Johnson, N.A., Stuart, C.T., Deming, J.W., Thies, R., Avery, R., 2006. Global bathymetric patterns of standing stock and body size in the deep-sea benthos. Marine Ecology Progress Series, 317, 18.

Rice, A.L., Lambshead, P.J.D., 1994. Patch dynamics in the deep-sea benthos: the role of a heterogeneous supply of organic matter. In: Guller, P.S., Hildrew, A.G., Raffaelli, D.G. (Eds), Aquatic Ecology: Scale pattern and process. Blackwell Scientific Publications, Oxford, pp. 469-498.

Rice, A.L., Billett, D.S.M., Thurston, M.H., Lampitt, R.S., 1991. The Institute of Oceanographic Sciences Biology Programme in the Porcupine Seabight: background and general introduction. Journal of the Marine Biological Association, UK, 71, 281-310.

Rice, A.L., Thurston, M.H., Bett, B.J., 1994. The IOSDL DEEPSEAS programme: introduction and photographic evidence for the presence and absence of a seasonal input of phytodetritus at contrasting abyssal sites in the northeastern Atlantic. Deep Sea Research Part I, 41, 1305-1320.

Rudnick, D.T., 1989 Time lags between the deposition and meiobenthic assimilation of phytodetritus. Marine Ecology Progress Series, 50, 231-240.
Ruhl, H.A., 2007. Abundance and size distribution dynamics of abyssal epibenthic megafauna in the northeast Pacific. Ecology, $88,1250-1262$

Ruhl, H.A., Smith, K.L., 2004. Shifts in deep-sea community structure linked to climate and food supply. Science, 305, 513-515.

Santos, V., Billett, D.S.M., Rice, A.L., Wolff, G.A., 1994. Organic matter in deep-sea sediments from the Porcupine Abyssal Plain in the north-east Atlantic Ocean. I-Lipids. Deep Sea Research Part I, 41, 787-819.

Shimanaga, M., Shirayama, Y., 2000. Response of benthic organisms to seasonal change of organic matter deposition in the bathyal Sagami Bay, central Japan. Oceanologica Acta, 23, 91-107.

Shirayama, Y., 1984a. Vertical distribution of meiobenthos in the sediment profile in bathyal, abyssal and hadal deep sea systems of the Western Pacific. Oceanologica Acta, 7, 123-129.

Shirayama, Y., 1984b. The abundance of deep-sea meiobenthos in the western Pacific in relation of environmental factors. Oceanologica Acta, 7, 113-121.

Soetaert, K., Vanaverbeke, J., Heip, C., Herman, P.M.J., Middelburg, J.J., Sandee, A., Duineveld, G., 1997. Nematode distribution in ocean margin sediments of the Goban Spur (Northeast Atlantic) in relation to sediment geochemistry. Deep Sea Research Part I, 44, 1671-1683.

Soltwedel, T., Pfannkuche, O., Thiel, H., 1996. The size structure of deep-sea meiobenthos in the north-eats Atlantic: nematode size spectra in relation to environmental variables. Journal of the Marine biological Association of the United Kingdom, 76, 327344.

Soltwedel, T., 1997. Meiobenthos distribution pattern in the tropical East Atlantic: indication for fractionated sedimentation of organic matter to the sea floor? Marine Biology, 129, 747-756.

Soltwedel, T., 2000. Metazoan meiobenthos along continental margins: a review. Progress in Oceanography, 46, 59-84

Soto, E.H., Paterson, G.L.J., Billett, D.S.M., Hawkins, L.E., Galéron, J., Sibuet, M., in press. Temporal variability in polychaete assemblages of the abyssal NE Atlantic Ocean. Deep Sea research Part II, this volume

Tahey, T.M., Duineveld, G.C.A., Berghuis, E.M., Helder, W., 1994. Relation between sediment- water fluxes of oxygen and silicate and faunal abundance at continental shelf, slope and deep-water stations in the northwest Mediterranean. Marine Ecology Progress Series, 104, 119-130.

Thiel, H., 1983. Meiobenthos and nanobenthos of the deep sea. In: Rowe, G.T. (Ed), The Sea, Volume 8. Wiley Interscience, New York, pp. 167-230.

Thiel, H., Pfannkuche, O., Schreiver, G., Lochte, K., Gooday, A.J., Hemleben, C., Mantoura, R.F.C., Turley, C.M., Patching, J.P., Riemann, F., 1989. Phytodetritus on the deep-sea floor in a central oceanic region of the Northeast Atlantic. Biological Oceanography, 6, 203-239.

Thistle, D., Ertman, S.C., Fauchald, K., 1991. The fauna of the HEBBLE site: patterns in standing stock and sediment-dynamic effects. Marine Geology, 99, 413-422.

Thistle, D., Eckman, J.E., Paterson, G.L.J., 2008. Large, motile epifauna interact strongly with harpacticoid copepods and polychaetes at a bathyal site. Deep Sea Research Part I: Oceanographic Research Papers, 55, 324-331.

Tietjen, J.H., 1992. Abundance and biomass of metazoan meiobenthos in the deep-sea. In: Rowe, G.T., Pariente, V. (Eds), Deep-Sea Food Chains and the Global Carbon Cycle. Kluwer Academic Publishers, The Netherlands, pp. 45-62.

Tietjen, J.H., Deming, J.W., Rowe, G.T., Macko, S., Wilke, R.J., 1989. Meiobenthos of the Hatteras Abyssal Plain and Puerto Rico Trench: abundance, biomass and associations with bacteria and particulate fluxes. Deep Sea Research Part I, 36, 1567-1577.

Tselepides, A., Lampadariou, N., 2004. Deep-sea meiofaunal community structure in the Eastern Mediterranean: are trenches benthic hotspots? Deep Sea Research Part I, 51, 833-847.

Vangriesheim, A., Springer, B., Crassous, P., 2001. Temporal variability of near-bottom particle resuspension and dynamics at the Porcupine Abyssal Plain, Northeast Atlantic. Progress in Oceanography, 50, 123-145.

Vanhove, S., Wittoeck, J., Desmet, G., Vandenberghe, B., Herman, R.L., Bak, R.P.M., Nieuwland, G., Vosjan, J.H., Boldrin, A., Rabitti, S., Vincx, M., 1995. Deep-sea meiofauna communities in Antarctica: structural analysis and relation with the environment. Marine Ecology Progress Series, 127, 65-76.

Vanreusel, A., Clough, L., Jacobsen, K., Ambrose, W., Jivaluk, J., Ryheul, V., Herman, R., Vincx, M., 2000. Meiobenthos of the 
central Arctic Ocean with special emphasis on the nematode community structure. Deep Sea Research Part I, 47, 1855-1879.

Vanreusel, A., Cosson-Sarradin, N., Gooday, A.J., Paterson, G.L.J., Galéron, J., Sibuet, M., Vincx, M., 2001. Evidence for episodic recruitment in a small opheliid polychaete species from the abyssal NE Atlantic. Progress in Oceanography, 50, 285-301.

Vanreusel, A., Vincx, M., Schram, D., Gansbeke, D., 1995. On the vertical distribution of the metazoan meiofauna in shelf break and upper slope habitats of the NE Atlantic. Internationale Revue der gesamte Hydrobiologie, 80, 313-326.

Varnavas, S.P., Panagiotaras, D., Wolff, G.A., 2001. Biogeochemical processes at the sediment-water interface in a Northeastern Atlantic abyssal locality (Porcupine Abyssal Plain). Progress in Oceanography, 50, 223-243.

Vincx, M., Bett, B.J., Dinet, A., Ferrero, T., Gooday, A.J., Lambshead, P.J.D., Pfannkuche, O., Soltwedel, T., Vanreusel, A., 1994. Meiobenthos of the deep northeast Atlantic. Advances in Marine Biology, 30, 2-88.

Wigham, B.D., Hudson, I.R., Billett, D.S.M., Wolff, G.A., 2003. Is long-term change in the abyssal Northeast Atlantic driven by qualitative changes in export flux? Evidence from selective feeding in deep-sea holothurians. Progress in oceanography, 59, 409-441.

Witbaard, R., Duineveld, G.C.A., Kok, A., van der Weele, J., Berghuis, E.M., 2001. The response of Oneirophanta mutabilis (Holothuroidea) to the seasonal deposition of phytopigments at the Porcupine Abyssal Plain in the Northeast Atlantic. Progress in oceanography, 50, 423-441.

Witbaard, R., Duineveld, G.C.A., Van der Weele, J.A., Berghuis, E.M., Reyss, J.P., 2000. The benthic response to the seasonal deposition of phytopigments at the Porcupine Abyssal Plain in the North East Atlantic. Journal of Sea Research, 43, 15-31.

Witte, U., Wenzhöfer, F., Sommer, S., Boetius, A., Heinz, P., Aberle, N., Sand, M., Cremer, A., Abraham, W.-R., Jørgensen, B.B. Pfannkuche, O., 2003. In situ experimental evidence of the fate of a phytodetritus pulse at the abyssal sea floor. Nature, 424, 763766.

Zar, J.H., 1999. Biostatistical analysis (4 $4^{\text {th }}$ edition). Prentice Hall, Upper Saddle River, New Jersey. 
Table 1

Station data for meiofauna samples obtained from the Porcupine Abyssal Plain Sustained Observatory site 1989-99. Station number, indicates the number of different samples (11908-54901: number of different cruises through the decade; \#No: number indicating the different multicorer deployments; $a / b$ : letter indicating core replicates of the same multicorer deployment where the average of abundances was obtained). Sorting, indicates the laboratory where the samples were analysed (DZMB: Deutsches Zentrum für Marine Biodiversitätsforschung; NOC: National Oceanography Centre, Southampton; UG: Universiteit Gent).

\begin{tabular}{|c|c|c|c|c|c|c|}
\hline \multirow{2}{*}{ Date } & \multirow{2}{*}{ Cruise } & \multirow{2}{*}{$\begin{array}{l}\text { Station } \\
\text { number }\end{array}$} & \multicolumn{2}{|c|}{ Position } & \multirow{2}{*}{$\begin{array}{c}\text { Depth } \\
\text { (m) }\end{array}$} & \multirow{2}{*}{ Sorting } \\
\hline & & & $\mathbf{N}$ & $\mathbf{W}$ & & \\
\hline \multirow[t]{2}{*}{ Aug 1989} & RRS Discovery 185 & 11908\#39 & $48^{\circ} 49.9^{\prime}$ & $16^{\circ} 30.1^{\prime}$ & 4845 & $\mathrm{NOC}$ \\
\hline & & $11908 \# 70$ & $48^{\circ} 49.5^{\prime}$ & $16^{\circ} 30.4^{\prime}$ & 4847 & NOC \\
\hline \multirow[t]{4}{*}{ May 1991} & RRS Challenger 79 & $52701 \# 10$ & $48^{\circ} 51.1^{\prime}$ & $16^{\circ} 28.7^{\prime}$ & 4843 & DZMB \\
\hline & & $52701 \# 24$ & $48^{\circ} 50.9^{\prime}$ & $16^{\circ} 29.2^{\prime}$ & 4845 & DZMB \\
\hline & & $52701 \# 27$ & $48^{\circ} 51.1^{\prime}$ & $16^{\circ} 29.2^{\prime}$ & 4847 & DZMB \\
\hline & & $52701 \# 51$ & $48^{\circ} 50.9^{\prime}$ & $16^{\circ} 29.9^{\prime}$ & 4843 & DZMB \\
\hline \multirow[t]{4}{*}{ April 1994} & RRS Challenger 111 & $53201 \# 7$ & $48^{\circ} 51.5^{\prime}$ & $16^{\circ} 30.5^{\prime}$ & 4837 & DZMB \\
\hline & & $53201 \# 9$ & $48^{\circ} 51.8^{\prime}$ & $16^{\circ} 29.7^{\prime}$ & 4845 & DZMB \\
\hline & & $53201 \# 11$ & $48^{\circ} 51.6^{\prime}$ & $16^{\circ} 29.9^{\prime}$ & 4847 & DZMB \\
\hline & & $53201 \# 17$ & $48^{\circ} 51.1^{\prime}$ & $16^{\circ} 29.6^{\prime}$ & 4846 & DZMB \\
\hline \multirow[t]{9}{*}{ Sep 1996} & RRS Discovery 222 & $12930 \# 10$ & $48^{\circ} 49.86^{\prime}$ & $16^{\circ} 29.54^{\prime}$ & 4838 & DZMB \\
\hline & & $12930 \# 15 a$ & $48^{\circ} 50.55^{\prime}$ & $16^{\circ} 29.84^{\prime}$ & 4837 & UG \\
\hline & & $12930 \# 15 b$ & $48^{\circ} 50.55^{\prime}$ & $16^{\circ} 29.84^{\prime}$ & 4837 & DZMB \\
\hline & & $12930 \# 18$ & $48^{\circ} 50.30^{\prime}$ & $16^{\circ} 29.03^{\prime}$ & 4837 & UG \\
\hline & & 12930\#29a & $48^{\circ} 50.15^{\prime}$ & $16^{\circ} 29.24^{\prime}$ & 4839 & UG \\
\hline & & $12930 \# 29 b$ & $48^{\circ} 50.15^{\prime}$ & $16^{\circ} 29.24^{\prime}$ & 4839 & UG \\
\hline & & $12930 \# 36 a$ & $48^{\circ} 51.26^{\prime}$ & $16^{\circ} 29.67^{\prime}$ & 4837 & UG \\
\hline & & 12930\#36b & $48^{\circ} 51.26^{\prime}$ & $16^{\circ} 29.67^{\prime}$ & 4837 & DZMB \\
\hline & & 12930\#66 & $48^{\circ} 50.25^{\prime}$ & $16^{\circ} 30.67^{\prime}$ & 4840 & DZMB \\
\hline \multirow[t]{10}{*}{ Mar 1997} & RRS Discovery 226 & $13077 \# 6 a$ & $48^{\circ} 50.90^{\prime}$ & $16^{\circ} 30.01^{\prime}$ & 4843 & UG \\
\hline & & $13077 \# 6 b$ & $48^{\circ} 50.90^{\prime}$ & $16^{\circ} 30.01^{\prime}$ & 4843 & UG \\
\hline & & $13077 \# 6 c$ & $48^{\circ} 50.90^{\prime}$ & $16^{\circ} 30.01^{\prime}$ & 4843 & DZMB \\
\hline & & $13077 \# 12$ & $48^{\circ} 50.17^{\prime}$ & $16^{\circ} 29.79^{\prime}$ & 4846 & DZMB \\
\hline & & $13077 \# 21$ & $48^{\circ} 50.02^{\prime}$ & $16^{\circ} 30.59^{\prime}$ & 4845 & UG \\
\hline & & $13077 \# 24$ & $48^{\circ} 49.97^{\prime}$ & $16^{\circ} 30.39^{\prime}$ & 4844 & DZMB \\
\hline & & 13077\#58a & $48^{\circ} 50.04^{\prime}$ & $16^{\circ} 29.96^{\prime}$ & 4844 & UG \\
\hline & & $13077 \# 58 b$ & $48^{\circ} 50.15^{\prime}$ & $16^{\circ} 29.67^{\prime}$ & 4844 & DZMB \\
\hline & & $13077 \# 60$ & $48^{\circ} 50.00^{\prime}$ & $16^{\circ} 29.97^{\prime}$ & 4845 & UG \\
\hline & & $13077 \# 69$ & $48^{\circ} 50.01^{\prime}$ & $16^{\circ} 30.07^{\prime}$ & 4843 & DZMB \\
\hline \multirow[t]{7}{*}{ Jul 1997} & RRS Discovery 229 & $13200 \# 1 a$ & $48^{\circ} 49.98^{\prime}$ & $16^{\circ} 30.00^{\prime}$ & 4843 & UG \\
\hline & & $13200 \# 1 b$ & $48^{\circ} 49.98^{\prime}$ & $16^{\circ} 30.00^{\prime}$ & 4843 & DZMB \\
\hline & & 13200\#1c & $48^{\circ} 49.98^{\prime}$ & $16^{\circ} 30.00^{\prime}$ & 4843 & UG \\
\hline & & 13200\#12 & $48^{\circ} 49.60^{\prime}$ & $16^{\circ} 29.68^{\prime}$ & 4842 & UG \\
\hline & & $13200 \# 24$ & $48^{\circ} 49.79^{\prime}$ & $16^{\circ} 29.21^{\prime}$ & 4844 & UG \\
\hline & & $13200 \# 32$ & $48^{\circ} 49.77^{\prime}$ & $16^{\circ} 28.90^{\prime}$ & 4843 & DZMB \\
\hline & & $13200 \# 46$ & $48^{\circ} 49.41^{\prime}$ & $16^{\circ} 29.85^{\prime}$ & 4844 & DZMB \\
\hline \multirow[t]{6}{*}{ Oct 1997} & RRS Challenger 135 & $54301 \# 9 b$ & $48^{\circ} 50.50^{\prime}$ & $16^{\circ} 31.3^{\prime}$ & 4843 & DZMB \\
\hline & & $54301 \# 10 a$ & $48^{\circ} 50.7^{\prime}$ & $16^{\circ} 28.6^{\prime}$ & 4843 & UG \\
\hline & & 54301\#10b & $48^{\circ} 50.7^{\prime}$ & $16^{\circ} 28.6^{\prime}$ & 4843 & UG \\
\hline & & $54301 \# 14$ & $48^{\circ} 50.4^{\prime}$ & $16^{\circ} 28.8^{\prime}$ & 4839 & UG \\
\hline & & $54301 \# 16$ & $48^{\circ} 50.6^{\prime}$ & $16^{\circ} 29.4^{\prime}$ & 4842 & UG \\
\hline & & $54301 \# 21$ & $48^{\circ} 49.1^{\prime}$ & $16^{\circ} 29.0^{\prime}$ & 4840 & DZMB \\
\hline \multirow[t]{8}{*}{ Mar 1998} & RRS Discovery 231 & $13368 \# 3$ & $48^{\circ} 49.11^{\prime}$ & $16^{\circ} 29.54^{\prime}$ & 4846 & UG \\
\hline & & $13368 \# 7$ & $48^{\circ} 49.49^{\prime}$ & $16^{\circ} 29.70^{\prime}$ & 4844 & DZMB \\
\hline & & 13368\#15 & $48^{\circ} 49.68^{\prime}$ & $16^{\circ} 29.51^{\prime}$ & 4845 & UG \\
\hline & & 13368\#19a & $48^{\circ} 51.09^{\prime}$ & $16^{\circ} 28.96^{\prime}$ & 4842 & UG \\
\hline & & 13368\#19b & $48^{\circ} 51.09^{\prime}$ & $16^{\circ} 28.96^{\prime}$ & 4842 & UG \\
\hline & & 13368\#19c & $48^{\circ} 51.09^{\prime}$ & $16^{\circ} 28.96^{\prime}$ & 4842 & DZMB \\
\hline & & $13368 \# 28 a$ & $48^{\circ} 50.06^{\prime}$ & $16^{\circ} 29.98^{\prime}$ & 4841 & UG \\
\hline & & $13368 \# 28 b$ & $48^{\circ} 50.06^{\prime}$ & $16^{\circ} 29.98^{\prime}$ & 4841 & DZMB \\
\hline \multirow[t]{2}{*}{ Sep 1998} & RRS Discovery 237 & $13627 \# 12$ & $48^{\circ} 49.90^{\prime}$ & $16^{\circ} 29.77^{\prime}$ & 4836 & DZMB \\
\hline & & $13627 \# 15$ & $48^{\circ} 49.93^{\prime}$ & $16^{\circ} 29.64^{\prime}$ & 4837 & UG \\
\hline \multirow[t]{4}{*}{ Apr 1999} & RRS Challenger 142 & $54901 \# 11$ & $48^{\circ} 50.3^{\prime}$ & $16^{\circ} 25.6^{\prime}$ & 4840 & DZMB \\
\hline & & $54901 \# 12$ & $48^{\circ} 50.2^{\prime}$ & $16^{\circ} 28.7^{\prime}$ & 4837 & DZMB \\
\hline & & $54901 \# 13$ & $48^{\circ} 49.4^{\prime}$ & $16^{\circ} 29.1^{\prime}$ & 4839 & DZMB \\
\hline & & $54901 \# 14$ & $48^{\circ} 49.9^{\prime}$ & $16^{\circ} 29.2^{\prime}$ & 4841 & DZMB \\
\hline
\end{tabular}


Table 2

Temporal variation in the meiobenthos of the Porcupine Abyssal Plain Sustained Observatory site (1989-1999). Mean densities of major taxa are given on a by cruise basis (see also Figure 3), together with nested ANOVA results for between period (1989-1994 vs. 1996-1999), year within period and cruise with year comparisons. ANOVA results are given for month irrespective of year comparisons. Period mean densities are also given with $95 \%$ confidence intervals (in parenthesis) for those taxa exhibiting significant between period variations. (ns - not significant).

\begin{tabular}{|c|c|c|c|c|c|c|c|c|c|c|c|c|c|c|c|c|}
\hline \multirow{2}{*}{ Taxon } & \multicolumn{10}{|c|}{$\begin{array}{c}\text { Cruise mean density } \\
\text { (indiv.10 } \mathrm{cm}^{2} \text { ) }\end{array}$} & \multicolumn{3}{|c|}{$\begin{array}{c}\text { Nested ANOVA } \\
(p)\end{array}$} & \multirow{2}{*}{\begin{tabular}{|c|}
$\begin{array}{c}\text { ANOVA } \\
(p)\end{array}$ \\
Month \\
\end{tabular}} & \multicolumn{2}{|c|}{$\begin{array}{l}\text { Period mean density } \\
\text { (indiv.10 } \mathrm{cm}^{2}{ }^{2} \text { ) }\end{array}$} \\
\hline & Aug'89 & May'91 & Apr'94 & Sep'96 & Mar'97 & Jul'97 & Oct ${ }^{\prime} 97$ & Mar'98 & Sep'98 & Apr'99 & Period & Year & Cruise & & $89-94$ & $96-99$ \\
\hline Nematodes & 409.2 & 584.8 & 301.3 & 671.4 & 609.7 & 842.2 & 777.9 & 747.5 & 756.5 & 935.5 & $<0.001$ & 0.011 & ns & ns & $\begin{array}{c}417.7 \\
(345.2-505.5)\end{array}$ & $\begin{array}{c}739.7 \\
(666.9-820.1)\end{array}$ \\
\hline Copepods & 35.5 & 54.7 & 34.4 & 51.6 & 40.0 & 45.3 & 44.8 & 40.4 & 29.2 & 58.1 & ns & ns & ns & ns & 41.7 & 44.5 \\
\hline Polychaetes & 1.6 & 7.6 & 1.9 & 18.8 & 12.3 & 10.1 & 10.5 & 9.2 & 6.5 & 8.7 & $<0.001$ & $<0.001$ & ns & 0.001 & $\begin{array}{c}3.3 \\
(2.2-5.0)\end{array}$ & $\begin{array}{c}11.2 \\
(9.1-13.8)\end{array}$ \\
\hline Oligochaetes & 0 & 0 & 0 & 0 & 0.1 & 0.5 & 0 & 0 & 0 & 0 & ns & ns & 0.031 & 0.010 & 0 & 0.1 \\
\hline Gastrotrichs & 0 & 0.9 & 0 & 0.9 & 0.4 & 0 & 0.2 & 0.3 & 0.5 & 0.5 & ns & 0.021 & ns & ns & 0.2 & 0.4 \\
\hline Ostracods & 4.2 & 2.4 & 2.1 & 0.8 & 0.5 & 0.5 & 0.3 & 0.4 & 0.9 & 3.0 & 0.019 & ns & ns & 0.007 & $\begin{array}{c}2.5 \\
(1.3-4.8)\end{array}$ & $\begin{array}{c}0.7 \\
(0.4-1.1)\end{array}$ \\
\hline Kinorhynchs & 0.3 & 0.3 & 0.2 & 0.2 & 0.1 & 0.1 & 0 & 0 & 0 & 0.9 & ns & 0.015 & ns & ns & 0.2 & 0.1 \\
\hline Molluscs & 0.4 & 0.4 & 0 & 0.2 & 0.1 & 0 & 0 & 0.2 & 0.2 & 0.1 & ns & ns & ns & ns & 0.2 & 0.1 \\
\hline Loriciferans & 0 & 1.6 & 0.4 & 0.8 & 0.7 & 0.4 & 0.2 & 0.4 & 0.3 & 1.8 & ns & ns & ns & ns & 0.6 & 0.6 \\
\hline Tantulocarids & 0 & 0.4 & 0.5 & 0 & 0.1 & 0.2 & 1.1 & 0 & 0 & 0.4 & ns & ns & ns & ns & 0.3 & 0.2 \\
\hline Others & 1.2 & 0.3 & 1.3 & 1.1 & 0.9 & 2.2 & 0.1 & 0.2 & 0.5 & 0.5 & ns & ns & ns & ns & 0.7 & 0.7 \\
\hline Total & 453.6 & 667.2 & 346.6 & 754.6 & 677.7 & 920.1 & 897.8 & 807.0 & 799.6 & 1073.5 & $\mid<0.001$ & 0.008 & ns & ns & $\begin{array}{c}475.3 \\
(393.4-574.5)\end{array}$ & $\begin{array}{c}823.5 \\
(743.3-912.6)\end{array}$ \\
\hline
\end{tabular}


Table 3

Temporal variation in the vertical distribution of selected meiofaunal taxa from the Porcupine Abyssal Plain Sustained Observatory site (1989-99); ANOVA results for comparisons of relative abundance in the $0-1 \mathrm{~cm}$ sediment horizon. Tests are shown for between cruise, year and period (1989-94 vs. 1996-99) comparisons. The results of by month (i.e. irrespective of year) comparisons are also given. (ns - not significant).

\begin{tabular}{l|c|ccc}
\multirow{2}{*}{ Taxon } & \multicolumn{4}{|c}{ ANOVA } \\
\cline { 2 - 5 } & Month & Cruise & Year & Period \\
\hline Nematodes & $<0.001$ & 0.001 & $\mathrm{~ns}$ & $\mathrm{~ns}$ \\
Copepods & 0.010 & 0.016 & 0.034 & 0.002 \\
Polychaetes & $\mathrm{ns}$ & $\mathrm{ns}$ & $\mathrm{ns}$ & 0.032 \\
Total meiobenthos & $<0.001$ & 0.001 & $\mathrm{~ns}$ & $\mathrm{~ns}$
\end{tabular}

Table 4. Spearman's rank correlations between selected environmental and biological variables for the Porcupine Abyssal Plain Sustained Observatory site, based on cruise mean values for the period 1989-1999 $(n=10)$. Significance levels are given where $p<0.05$ and are highlighted with boxes.

\begin{tabular}{|c|c|c|c|c|c|c|c|}
\hline & Phyto $^{1}$ & Model $^{2}$ & Model $^{3}$ & ${ }^{3} \mathrm{NAO}^{4}$ & $\mathrm{NAO}^{5}$ & A. $^{6}$ & $\operatorname{Mega}^{7}$ \\
\hline & score & flux & flux-1 & DJFM & DJFM-1 & rosea & MDSx \\
\hline Model flux & 0.184 & & & & & & \\
\hline Model flux-1 & 0.593 & 0.000 & & & & & \\
\hline NAO DJFM & -0.079 & 0.800 & 0.000 & & & & \\
\hline & & 0.005 & & & & & \\
\hline NAO DJFM-1 & 0.217 & 0.550 & 0.125 & 0.125 & & & \\
\hline A. rosea & -0.428 & -0.874 & -0.357 & -0.702 & -0.640 & & \\
\hline & & 0.001 & & 0.024 & 0.046 & & \\
\hline Mega MDSx & -0.279 & -0.886 & -0.246 & -0.689 & -0.689 & 0.976 & \\
\hline & & 0.001 & & 0.027 & 0.027 & 0.000 & \\
\hline Nematodes $^{8}$ & -0.240 & \begin{tabular}{|l|}
-0.665 \\
\end{tabular} & -0.025 & -0.320 & -0.320 & 0.527 & 0.552 \\
\hline & & 0.036 & & & & & \\
\hline Copepods $^{8}$ & 0.084 & -0.351 & 0.572 & -0.388 & 0.289 & 0.030 & 0.055 \\
\hline Polychaetes $^{8}$ & -0.156 & -0.862 & -0.025 & -0.911 & -0.172 & 0.758 & 0.733 \\
\hline & & 0.001 & & 0.000 & & 0.011 & 0.016 \\
\hline Ostracods ${ }^{8}$ & 0.389 & 0.671 & 0.535 & 0.659 & 0.474 & -0.855 & -0.794 \\
\hline & & 0.034 & & 0.038 & & 0.002 & 0.006 \\
\hline Total meiob ${ }^{8}$ & -0.279 & $\begin{array}{l}-0.665 \\
\end{array}$ & -0.025 & -0.320 & -0.320 & 0.539 & 0.564 \\
\hline & & 0.036 & & & & & \\
\hline Meiob MDSx ${ }^{y}$ & 0.240 & \begin{tabular}{|l|}
0.665 \\
\end{tabular} & 0.025 & 0.320 & 0.320 & -0.527 & -0.552 \\
\hline & & 0.036 & & & & & \\
\hline
\end{tabular}

\footnotetext{
${ }^{1}$ Phytodetritus index from Bett et al. (2001); ${ }^{2}$ Modelled organic carbon flux to seafloor from Lampitt et al. (2001); ${ }^{3}$ The same lagged by one year; ${ }^{4}$ Winter (December-March) average North Atlantic Oscillation index (Jones et al., 1997); ${ }^{5}$ The same lagged by one year; ${ }^{6}$ Amperima rosea mean density from Billett et al. (this volume); ${ }^{7}$ Megabenthos taxon composition as multi-dimensional scaling x-ordinate from Billett et al. (this volume); ${ }^{8}$ Meiobenthos taxon mean density from present study; ${ }^{9}$ Meiobenthos taxon composition as multi-dimensional scaling $\mathrm{x}$-ordinate from present study.
} 


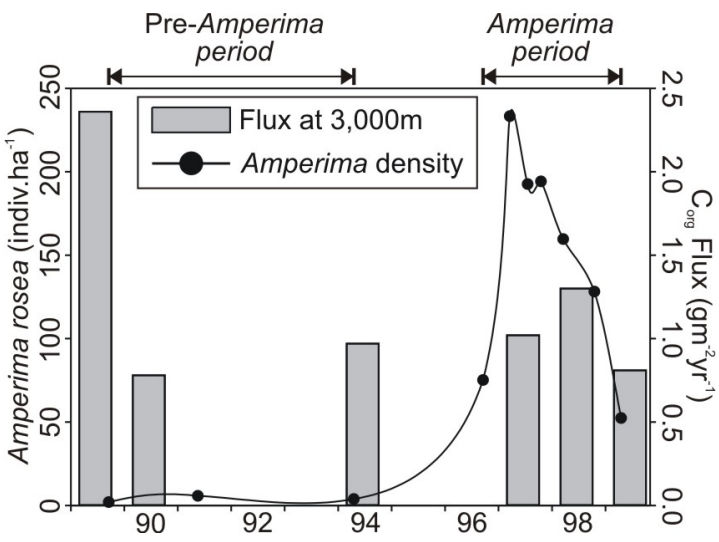

Fig. 1. Temporal variations in Amperima rosea (holothurian) density and organic carbon flux at the Porcupine Abyssal Plain Sustained Observatory site. "Pre-Amperima" and "Amperima" periods are indicated as referred to in the text. (After: Billett et al. in press; Lampitt et al. in press).
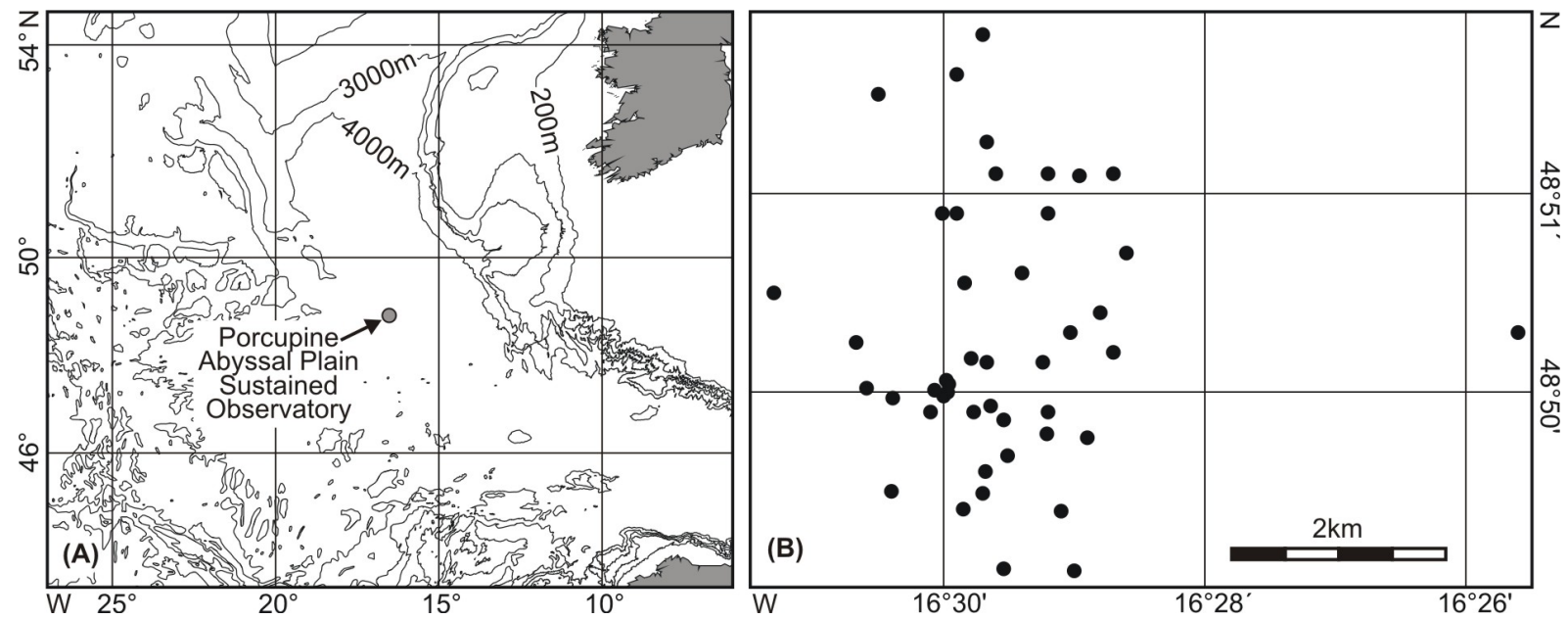

Fig. 2. Charts showing (A) the general location of the Porcupine Abyssal Plain Sustained Observatory site and (B) the disposition of samples assessed in the present study (see also Table 1). 

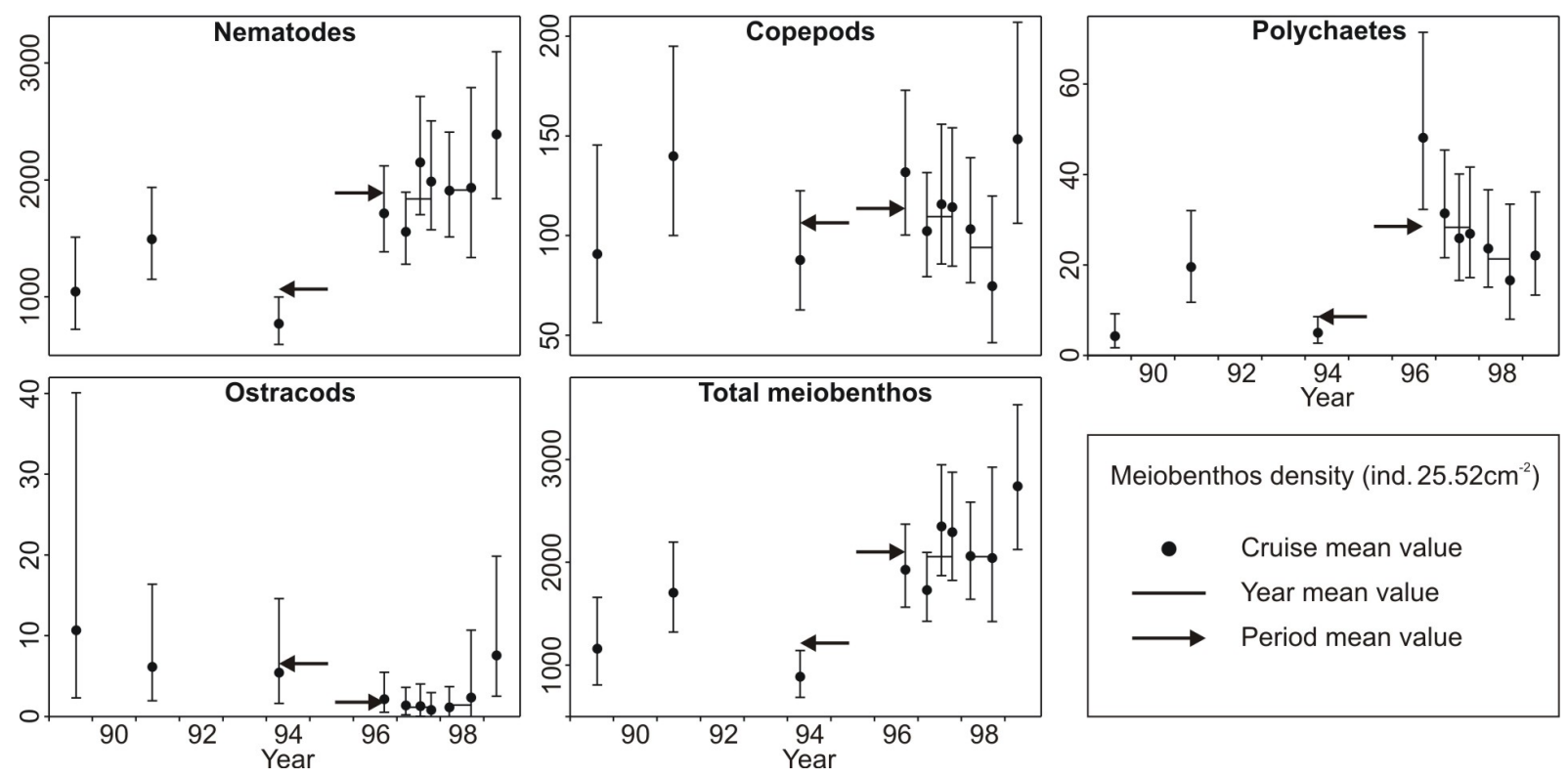

Fig. 3. Plots of temporal variations in the density of selected meiobenthic taxa at the Porcupine Abyssal Plain Sustained Observatory site; cruise means with 95\% confidence intervals are shown together with indications of year means (1997 and 1998) and period means (1989-94 and 1996-99).
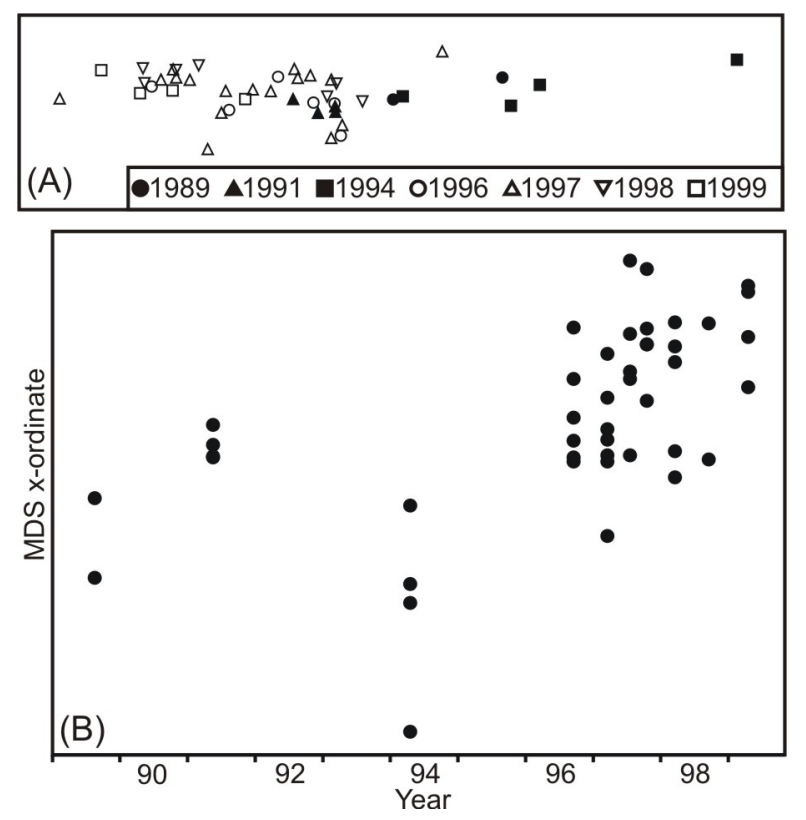

Fig. 4. Temporal variations in the composition of meiobenthic taxa at the Porcupine Abyssal Plain Sustained Observatory; (A) non-metric multi-dimensional scaling (MDS) ordination, note filled symbols represent the "pre-Amperima period" (1989-94) and open symbols the "Amperima period" (1996-99) (nMDS stress, 0.02); (B) plot of temporal variation in the MDS-x ordinate. 


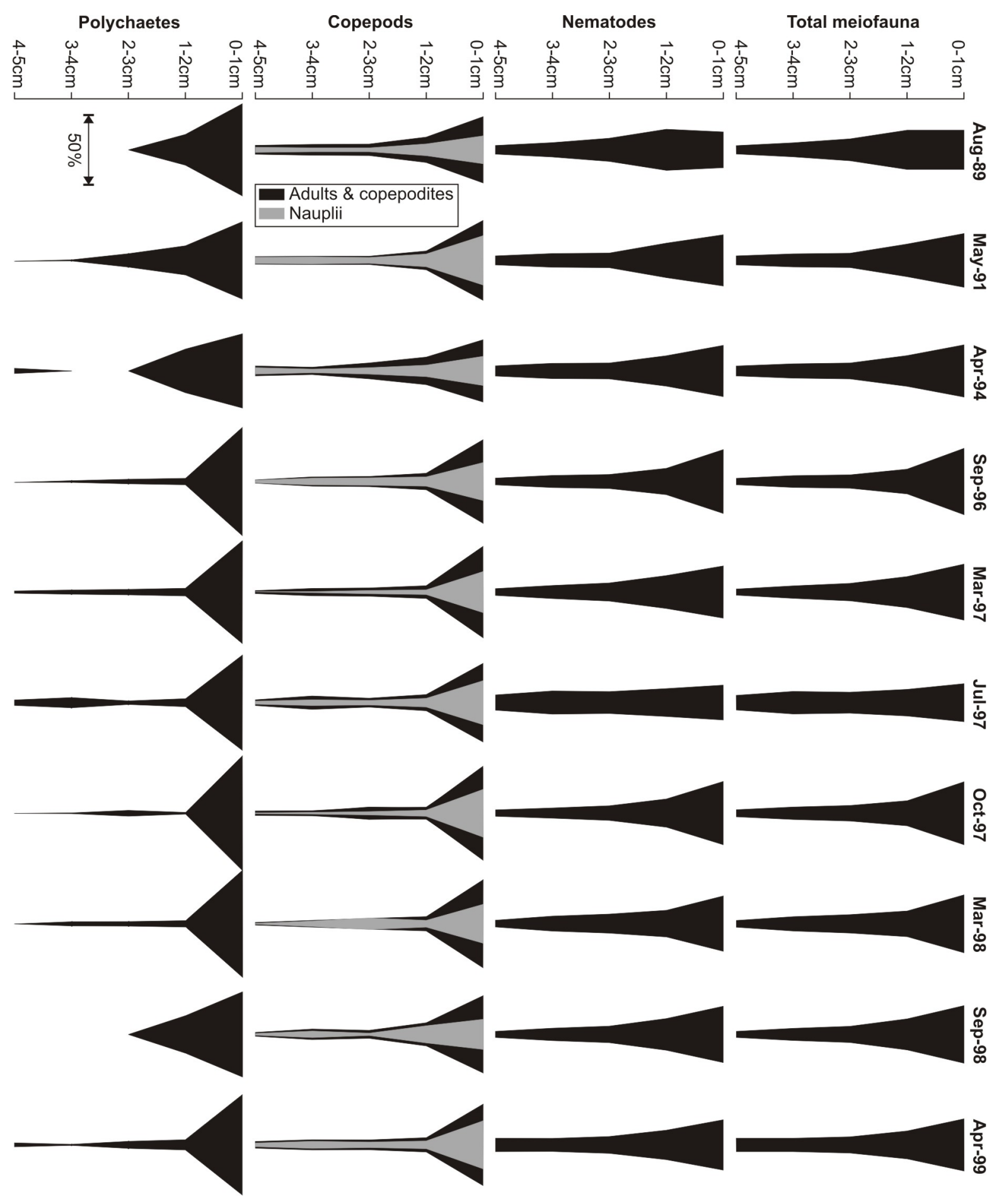

Fig. 5. Temporal variations in the vertical profiles of mean relative abundance in $1 \mathrm{~cm}$ horizons $(0-5 \mathrm{~cm})$ for the dominant meiofaunal taxa at the Porcupine Abyssal Plain Sustained Observatory site. 

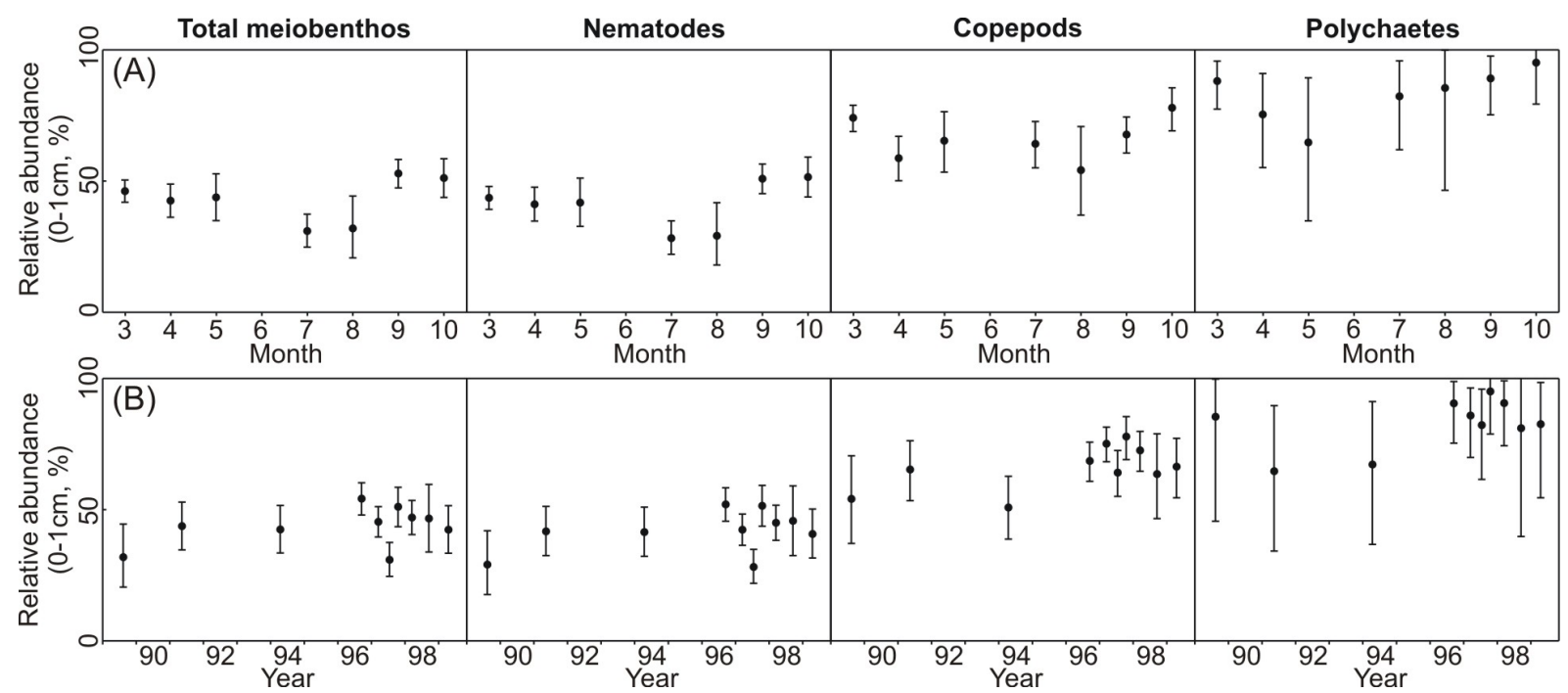

Fig. 6. Temporal variation in the relative abundance (mean and $95 \%$ confidence interval) of selected meiofaunal taxa in the $0-1 \mathrm{~cm}$ sediment layer at the Porcupine Abyssal Plain Sustained Observatory site; (A) data arranged by month irrespective of year; (B) data arranged by cruise date. 